\title{
Phosphorus thresholds for bloom-forming cyanobacterial taxa in boreal lakes
}

\author{
Kristiina Vuorio (1D) Marko Järvinen • Niina Kotamäki
}

Received: 5 July 2019/Revised: 4 November 2019/Accepted: 10 December 2019/Published online: 26 December 2019

(C) The Author(s) 2019

\begin{abstract}
Cyanobacteria may limit recreational use of waters and have negative impacts on ecosystem services. The aim of this study was to determine phosphorus (P) thresholds for cyanobacterial taxa, which form toxin-producing blooms (mass occurrences) in boreal lakes. These thresholds help to set robust $\mathrm{P}$ reduction targets for restoration measures. We used long-term ( $>40$ years) June-August data from $>2000$ Finnish lakes to evaluate the total P (TP) thresholds for the most important bloom-forming cyanobacterial genera and selected Microcystis and Dolichospermum species. The analyses were carried out separately for oligohumic, mesohumic and polyhumic lakes. TP threshold values varied between 10 and $61 \mu \mathrm{g} \mathrm{l}^{-1}$. The values were lower in oligohumic (water colour $<30 \mathrm{mg} \mathrm{Pt}^{-1}$ ) than mesohumic (water colour 30-90 mg Pt $1^{-1}$ ) lakes. The highest TP threshold $\left(50 \mu \mathrm{g} \mathrm{l}^{-1}\right)$ was observed for Microcystis
\end{abstract}

Guest editors: Tom Jilbert, Raoul-Marie Couture, Brian J. Huser \& Kalevi Salonen / Restoration of eutrophic lakes: current practices and future challenges

K. Vuorio $(\bowtie) \cdot$ M. Järvinen

Finnish Environment Institute (SYKE), Freshwater Centre, Latokartanonkaari 11, 00790 Helsinki, Finland

e-mail: kristiina.vuorio@ymparisto.fi

N. Kotamäki

Finnish Environment Institute (SYKE), Freshwater

Centre, Survontie 9A, 40500 Jyväskylä, Finland in polyhumic lakes, and the lowest $\left(10 \mu \mathrm{g}^{-1}\right)$ for Planktothrix in oligohumic lakes.

Keywords Phosphorus reduction target .

Microcystis · Dolichospermum · Aphanizomenon .

Woronichinia

\section{Introduction}

Nuisance cyanobacterial blooms (i.e. high cyanobacterial biomass in the epilimnion) are the most visible consequence of anthropogenic eutrophication. Current climate change, which results in higher temperatures, is expected to increase the occurrence, duration and intensity of these blooms (Weyhenmeyer et al., 2002; Paerl \& Huisman, 2008; Wagner \& Adrian, 2009). Cyanobacteria have many adverse impacts. Because cyanobacteria are capable of producing toxins (e.g. WHO, 2003; Codd et al., 2005), they have negative impacts on the provision of ecosystem services (e.g. Carvalho et al., 2013). The presence of potentially toxic cyanobacteria poses serious health risks to water supply, irrigation and recreational use (WHO 2003, 2004), and degrades the ecological status of water bodies (Carvalho et al., 2011, 2012). In addition, decomposing cyanobacterial scums can cause hypoxia, leading to fish kills (e.g. Paerl et al., 2001; Codd et al., 2005). The most serious consequences of toxic 
cyanobacteria are poisonings of humans, pets and livestock (Codd et al., 1999).

In addition to their potential toxicity, cyanobacteria are poor quality food for organisms higher in the food chain. They form aggregates that are too large to be ingested by zooplankton, and they contain lower amounts of many important biomolecules (amino acids, fatty acids and sterols), essential for the growth and reproduction of zooplankton and fish (e.g. Taipale et al., 2013; Peltomaa et al., 2017). This has negative impacts on the structure and functioning of the food web (e.g. Dokulil \& Teubner, 2000) due to weak energy flow to higher trophic levels (e.g. Elliott, 2012). Climate change is expected to increase the adverse impacts of cyanobacteria on aquatic ecosystems, since higher temperatures are predicted to increase both duration and intensity of cyanobacterial blooms (e.g. Paerl \& Huisman, 2009; Huber et al., 2012).

Reduction of cyanobacterial biomass is often the most important goal of lake restoration. The prerequisite for reducing the abundance of cyanobacteria is to understand the mechanisms most favourable to them. Formation of cyanobacterial masses requires sufficient nutrients, especially $\mathrm{P}$, the presence of species that can form a bloom, and environmental conditions should also favour the growth of only a few bloom-forming taxa (e.g. Reynolds, 2006). The dominance of cyanobacteria has been linked to high water temperature, low ratio of total nitrogen (TN) to total phosphorus (TP), superior uptake kinetics for inorganic carbon, high-nutrient storage capacity, presence of gas vacuoles enabling buoyancy regulation, and grazing resistance (e.g. Shapiro, 1990; Dokulil \& Teubner, 2000). Although nitrogen (N) may also play an important role in some shallow lakes (e.g. Paerl et al., 2001), phosphorus (P) is most often a major determinant of the proportion of cyanobacteria in freshwater phytoplankton communities (e.g. Downing et al., 2001; Carvalho et al., 2013; Maileht et al., 2013).

Many studies have demonstrated that nutrient reduction is the most effective way to reverse the effects of eutrophication and mitigate harmful cyanobacterial blooms (e.g. Carvalho et al., 2011, 2013). Since P is the major nutrient controlling algal growth (e.g. Downing et al., 2001; Carvalho et al., 2013; Maileht et al., 2013), various measures have been applied to reduce internal and external $\mathrm{P}$ load (e.g. Søndergaard et al., 2008; Triest et al., 2016). The greatest challenge in this respect is to properly assess and set the P reduction target for the water body.

Some studies have assessed critical nutrient thresholds for bloom-forming cyanobacteria (e.g. Wagner \& Adrian, 2009; Chorus \& Schauser, 2011; Xu et al., 2014). However, to our best knowledge, studies assessing genus- or species-specific thresholds are largely lacking. The objective of our study is to provide TP thresholds for the most important bloomforming cyanobacterial genera (Aphanizomenon, Dolichospermum, Microcystis, Woronichinia and Planktothrix) and for the most common Dolichospsermum and Microcystis species. Consideration of genusand species-specific TP thresholds should help lake management set proper precautionary $\mathrm{TP}$ reduction targets for boreal lakes.

\section{Materials and methods}

The data were obtained from the phytoplankton, water quality and lake physiography databases of the Finnish Environment Institute (SYKE; Open data portal http:// www.syke.fi/en-US/Open_information) representing results of surveillance and operational monitoring since the 1960's. For the study period, we selected the late summer data from the beginning of July to the end of August, which is a typical time for the high levels of cyanobacterial biomasses and blooms in Finnish lakes. To avoid any effects of changes in the water chemistry and phytoplankton methodology on the data (Mitikka \& Ekholm, 2006), the period 1977-2016 was selected for the study.

\section{Cyanobacteria data}

A total of 7219 phytoplankton samples from 2186 lakes were used in the analysis. The majority (90\%) of phytoplankton samples represent the uppermost $2 \mathrm{~m}$ (0-2 m) of the water column. The rest of the phytoplankton samples represent a water column down to a depth of 5 or $10 \mathrm{~m}$ depth. Phytoplankton samples, preserved with acid Lugol's solution, were analysed using Utermöhl technique (CEN EN 14204, 2006).

Wet weight $\left(\mathrm{mg} \mathrm{l}^{-1}\right)$ was used to assess the biomass of cyanobacteria. Because different species have different nutrient requirements (Reynolds, 2006), 
TP thresholds were determined separately for the most abundant cyanobacterial genera Microcystis, Woronichinia, Aphanizomenon, Dolichospermum and Planktothrix. In addition, TP thresholds were determined for the species Microcystis aeruginosa, M. viridis, $M$. wesenbergii, and for the coil-forming Dolichospermum flosaquae and D. lemmermannii, and for a complex of Dolichospermum species that form straight filaments (aggregate biomass of D. macrospora, D. planctonicum and D. solitarium).

\section{Water chemistry and physiography}

Water chemistry results for TP and water colour, measured from samples taken at 1-m depth, represent the same water layer and sampling dates as the phytoplankton samples. Water chemistry analyses were performed according to the standard methods described in Mitikka \& Ekholm (2003).

For the statistical analysis, lakes were classified into three water colour groups: oligohumic $(<30 \mathrm{mg}$ $\mathrm{Pt}^{-1}$ ), mesohumic (30-90 $\mathrm{mg} \mathrm{Pt}^{-1}$ ) and polyhumic (>90 mg Pt $^{-1}$ ) lakes. Based on the TP concentrations, the lakes were further classified into four groups: oligotrophic $\quad\left(<20 \mu \mathrm{g} \mathrm{l}^{-1}\right), \quad$ mesotrophic (20-40 $\mu \mathrm{g}^{-1}$ ), eutrophic (40-60 $\mu \mathrm{g}^{-1}$ ) or hypereutrophic $\left(>60 \mu \mathrm{g}^{-1}\right.$ ) (modified from Vollenweider, 1968; Jones \& Lee, 1986).

\section{Statistical analysis}

Smoothed scatterplots were used to visualise the relationship between cyanobacterial biomass and TP, and the possibility of a change point. In the study, we were interested in the first change point for the cyanobacteria biomass increase. As the biomass of cyanobacteria started to level off at TP concentrations of roughly $>100 \mu \mathrm{g} \mathrm{l}^{-1}$, the TP gradient was cut to $100 \mu \mathrm{g}^{-1}$ for statistical analysis, as was also done by Carvalho et al. (2013).

The TP thresholds were estimated using a segmented regression model (Gallant \& Fuller, 1973; Muggeo, 2003). This method is also called piecewise, hockey-stick or broken-line regression model. It allows fitting separate lines to different segments of the data. The boundary value of these segments is the threshold (often also called breakpoint, change point or switch point). In general, the segmented regression method fits two (or more) distinct linear regression lines with the maximum difference between the slopes (Muggeo, 2003).

The analysis was done using a segmented package (v. 0.5-4.0; Muggeo, 2008) of R 3.5.0 (R Core Team, 2018). As a default of the method, the starting value of the change point estimation is set to the median TP of each data subset. However, in some cases, the segmented iteration was sensitive to the starting values and the algorithm could not find the global maximum, which produced arbitrary thresholds. In some cases the method could not produce thresholds due to low number data or consistently low biomass for some taxa (e.g. Dolichospermum lemmermannii) or the threshold was not set to a clear biomass increase point (e.g. Microcystis). In such cases the threshold was assessed by visual inspection. These thresholds are marked with an asterisk in the result table.

\section{Results}

Cyanobacterial biomass and composition

Our classified data consisted of 5678 phytoplankton samples from 2029 lakes, representing mean TP values between 1 and $470 \mu \mathrm{g} 1^{-1}$ and water colour between 1 and $490 \mathrm{mg} \mathrm{Pt}^{-1}$ (Table 1). The data was dominated by (70\%) results from stratified lakes with a mean depth $>3 \mathrm{~m}$. About $54 \%$ of the results represented samples from oligotrophic lakes (TP $<20 \mu \mathrm{g} \mathrm{l}^{-1}$ ), and only $12 \%$ of the results represented hypereutrophic lakes (TP $>60 \mu \mathrm{g} \mathrm{l}^{-1}$ ). Most of the lakes (more than $80 \%$ ) were humic lakes (water colour $>30 \mathrm{mg} \mathrm{Pt}^{-1}$ ), and $33 \%$ of the lakes were polyhumic ( $>90 \mathrm{mg} \mathrm{Pt} \mathrm{l}^{-1}$ ). Alkalinity was low $\left(<0.2 \mathrm{mmol}^{-1}\right)$ in $53 \%$ of the lakes and only in less than $0.5 \%$ of the lakes had alkalinity of $>1 \mathrm{mmol} \mathrm{l}^{-1}$.

Cyanobacteria were present in almost all samples (99.98\%). Cyanobacteria were absent or had very low biomass at TP concentrations below $10 \mu \mathrm{g} 1^{-1}$ (Fig. 1). The average and median biomass of cyanobacteria increased with increasing TP (Figs. 1, 2 and Table 2). This was evident especially at TP concentrations $>20 \mu \mathrm{g} \mathrm{l}^{-1}$, but the variation was high (Fig. 1). On a log-log scale, the total cyanobacterial biomass increased linearly along the TP concentration gradient from 20 to $100 \mu \mathrm{g}^{-1}$ (Fig. 1). The increase in average and median cyanobacterial 
Table 1 Number of lakes in each total phosphorus (TP) and water colour category

\begin{tabular}{llccrr}
\hline Water colour mg Pt ${ }^{-1}$ & \multicolumn{2}{l}{ TP $\mu \mathrm{g} \mathrm{l^{-1 }}$} & & Total \\
\cline { 2 - 5 } & $<20$ & $20-40$ & $40-60$ & $>60$ & \\
\hline$<30$ & 284 & 48 & 16 & 18 & 366 \\
$30-90$ & 500 & 288 & 108 & 96 & 992 \\
$>90$ & 136 & 258 & 139 & 139 & 671 \\
Total & 920 & 594 & 263 & 252 & 2029 \\
\hline
\end{tabular}

Fig. 1 Log-log scatterplot and smoothed regression line of total cyanobacterial biomass and total phosphorus (TP). Vertical grey area represents 20 and $100 \mu \mathrm{g}^{-1} \mathrm{TP}$ range for linear increase in cyanobacterial biomass. The horizontal dotted lines indicate the low health risk threshold ( $\left.2 \mathrm{mg} \mathrm{l}^{-1}\right)$ and medium health risk threshold $\left(10 \mathrm{mg} \mathrm{l}^{-1}\right)$ (WHO, 2003)

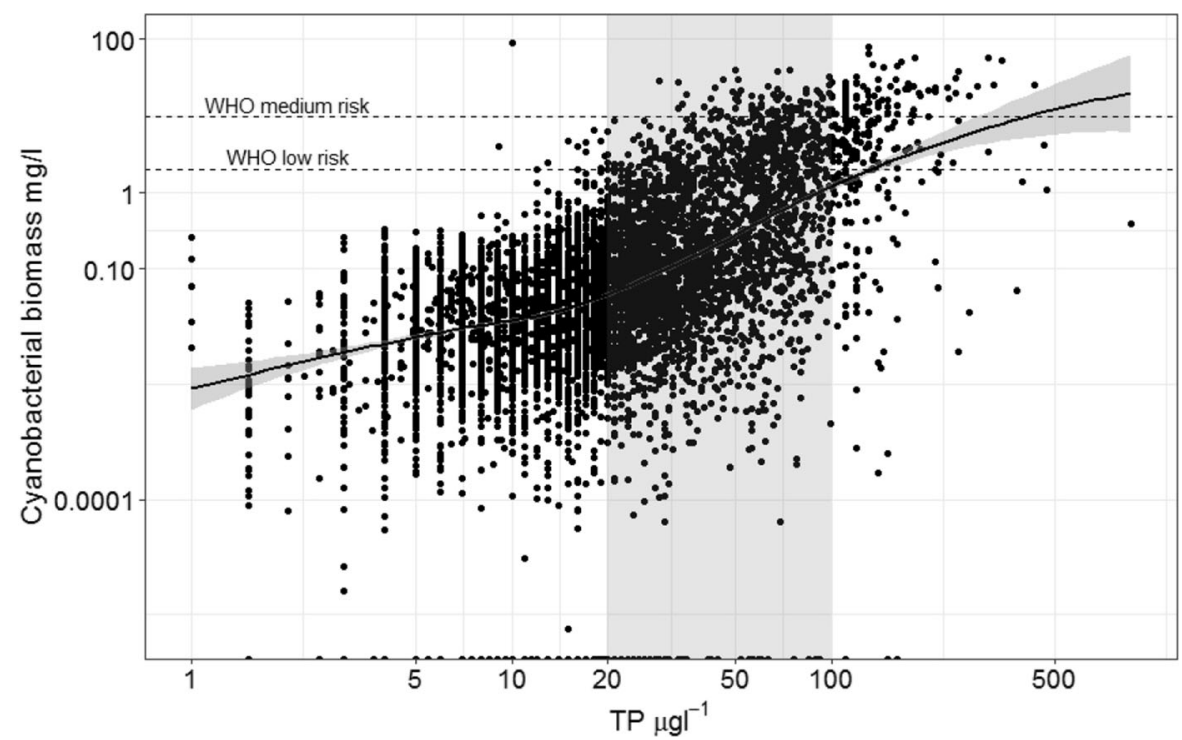

total biomass was also evident within different TP categories (<20, 20-40, 40-60, > $60 \mu \mathrm{g}^{-1}$, Fig. 2). Within the TP categories, the average biomass of cyanobacteria was higher in the oligohumic lakes and lower in the polyhumic lakes, except in the TP category $<20 \mu \mathrm{g} \mathrm{l}^{-1}$, where cyanobacterial biomass was highest in the mesohumic lakes (Fig. 2).

At genus level, Aphanizomenon had the highest average biomass in hypereutrophic (TP $>60 \mu \mathrm{g}^{-1}$ ) oligohumic lakes, although its median biomass was highest in hypereutrophic mesohumic lakes (Table 2). Dolichospermum average biomass was high at $\mathrm{TP}>40 \mu \mathrm{g}^{-1}$ in mesohumic and polyhumic lakes (average $\quad 1500-2000 \mu \mathrm{g} \mathrm{l}^{-1}$, median ca $70-500 \mu \mathrm{g} \mathrm{l}^{-1}$ ). At species level, the complex of straight-filamented Dolichospermum species was more abundant than the coiled colonies forming Dolichospermum complex (aggregate biomass of $D$. flosaquae $+D$. lemmermannii) in all TP and water colour categories, except in the oligohumic lakes in the TP category 40-60 $\mu \mathrm{g} 1^{-1}$. Microcystis was most abundant in hypereutrophic oligohumic lakes (average ca $1800 \mu \mathrm{g}^{-1}$ and median $660 \mu \mathrm{g}^{-1}$ ). The average biomasses of Microcystis aeruginosa and M. wesenbergii were higher (ca 500-750 $\mu \mathrm{g} \mathrm{l}^{-1}$ ) in hypereutrophic oligohumic and mesohumic lakes. Similarly, the highest average Planktothrix biomass (ca 500-700 $\mu \mathrm{g}^{-1}$ ) was found in hypereutrophic oligohumic and mesohumic lakes. The average biomasses of M. viridis and Woronichinia were low $\left(<200 \mu \mathrm{g} \mathrm{l}^{-1}\right)$ in all lake TP and colour categories (Table 2).

Phosphorus thresholds for cyanobacteria

The TP thresholds for the cyanobacterial biomass increase, determined by the segmented regression, are presented in Table 3 and Fig. 3. The TP threshold value for cyanobacterial biomass, including all cyanobacterial taxa present in the samples, was $30 \mu \mathrm{g} \mathrm{l}^{-1}$ (Table 3, Fig. 3). At the genus level, the TP thresholds were lowest for Aphanizomenon 


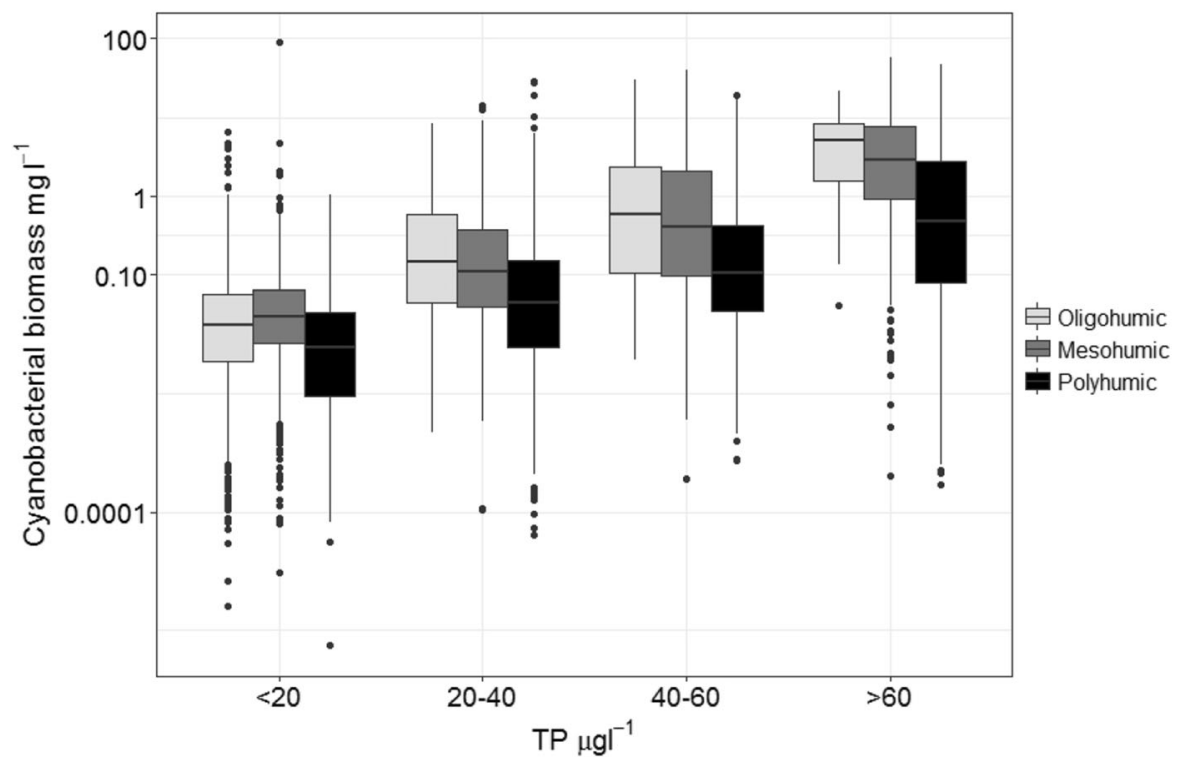

Fig. 2 Boxplot of total cyanobacterial biomass in lakes with different total phosphorus (TP) concentration and water colour: oligohumic (water colour $<30 \mathrm{mg} \mathrm{Pt}^{-1}$ ), mesohumic (water colour 30-90 $\mathrm{mg} \mathrm{Pt}^{-1}$ ) and polyhumic (water colour $>90 \mathrm{mg}$ $\mathrm{Pt} \mathrm{l}^{-1}$ ). On each box, the horizontal line indicates the median,

$19 \mu \mathrm{g} \mathrm{l}^{-1}$, Woronichinia $24 \mu \mathrm{g}^{-1}$ and Planktothrix ca $19 \mu \mathrm{g}^{-1}$. The TP threshold for Microcystis was slightly above $20 \mu \mathrm{g}^{-1}$ based on visual inspection of the plot (Fig. 3) and $50 \mu \mathrm{g}^{-1}$ according to the segmented gradient analysis. The genus Dolishospermum had a TP threshold of $24 \mu \mathrm{g}^{-1}$, and it was higher for $D$. flosaquae $\left(46 \mu \mathrm{g}^{-1}\right)$. The $95 \%$ confidence intervals for the $\mathrm{P}$ thresholds for all cyanobacterial taxa were relatively narrow, with a distance between the lower and the upper limit less than $15 \mathrm{~g} \mathrm{l}^{-1}$ (Table 3) The confidence intervals were wider for all taxa in polyhumic lakes $\left(17-54 \mu \mathrm{g} \mathrm{l}^{-1}\right)$, as well as for the straight-filamented Dolichospermum complex (25 $\mathrm{g} \mathrm{l}^{-1}$; all lakes) and for Woronichinia in mesohumic lakes $\left(27 \mu \mathrm{g}^{-1}\right)$.

\section{Discussion}

Different phytoplankton species have species-specific growth requirements (e.g. Reynolds, 2006). This also complicates the generalization of the response of cyanobacteria to environmental forcing at lower taxonomic level. The high cyanobacterial biomasses are ultimately dependent on bottom-up (nutrient) and the bottom and top edges of the box indicate the 25th and 75 th percentiles, respectively. The whiskers extend to the most extreme data points not considered outliers, and the outliers are plotted individually with points

control and complex food web interactions (e.g. Dokulil \& Teubner, 2000). Because cyanobacteria are poor quality food and often too large for zooplankton to ingest, successful management of cyanobacteria solely by grazers is in most cases unlikely, meaning that $\mathrm{TP}$ reduction is required to reduce cyanobacterial biomass (e.g. Bormans et al., 2016). There is strong evidence that reduction of TP concentration may be the most feasible and practical approach to long-term management of cyanobacterial biomass (e.g. Paerl \& Paul, 2012; Fastner et al., 2016).

We focused on the biomass of cyanobacteria, which ultimately affects the recreational quality and safety of waters (WHO, 2003, 2004). Our results indicate that the biomass of cyanobacteria starts to increase strongly at the TP level of ca $20 \mu \mathrm{g} \mathrm{l}^{-1}$, which is approximately the WHO low-risk threshold for cyanotoxins (Carvalho et al., 2013). This threshold concentration is in agreement with a German study, where the occurrence of high cyanobacterial biomass was significantly less likely at TP levels $<25 \mu \mathrm{g} \mathrm{l}^{-1}$ (Chorus \& Schauser, 2011). In our study, cyanobacteria were almost absent in TP levels $<10 \mu \mathrm{g} \mathrm{l}^{-1}$, which could be considered as a lower (pre-cautionary) threshold for massive increase of cyanobacterial 
4394

Hydrobiologia (2020) 847:4389-4400

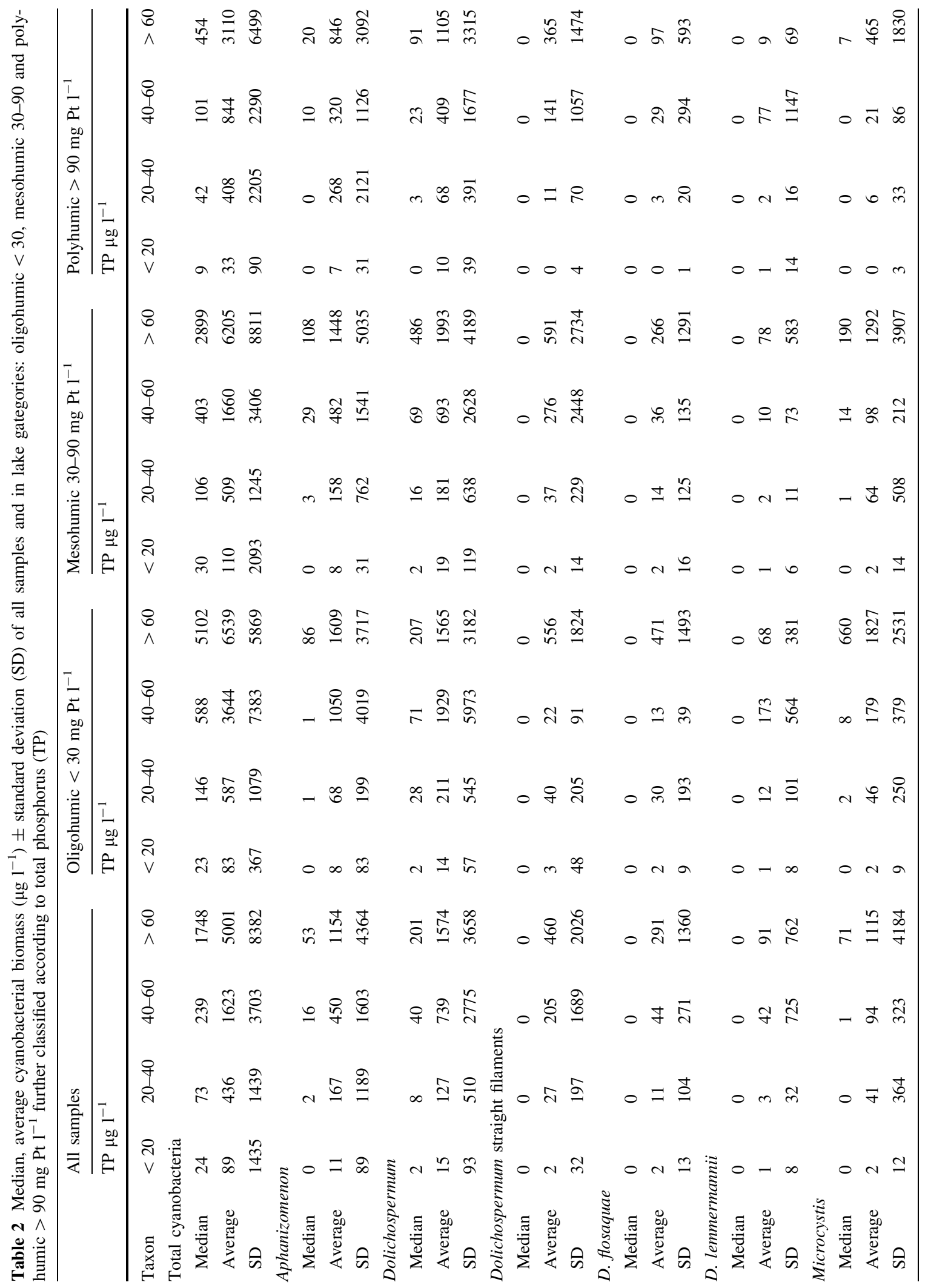

Springer 


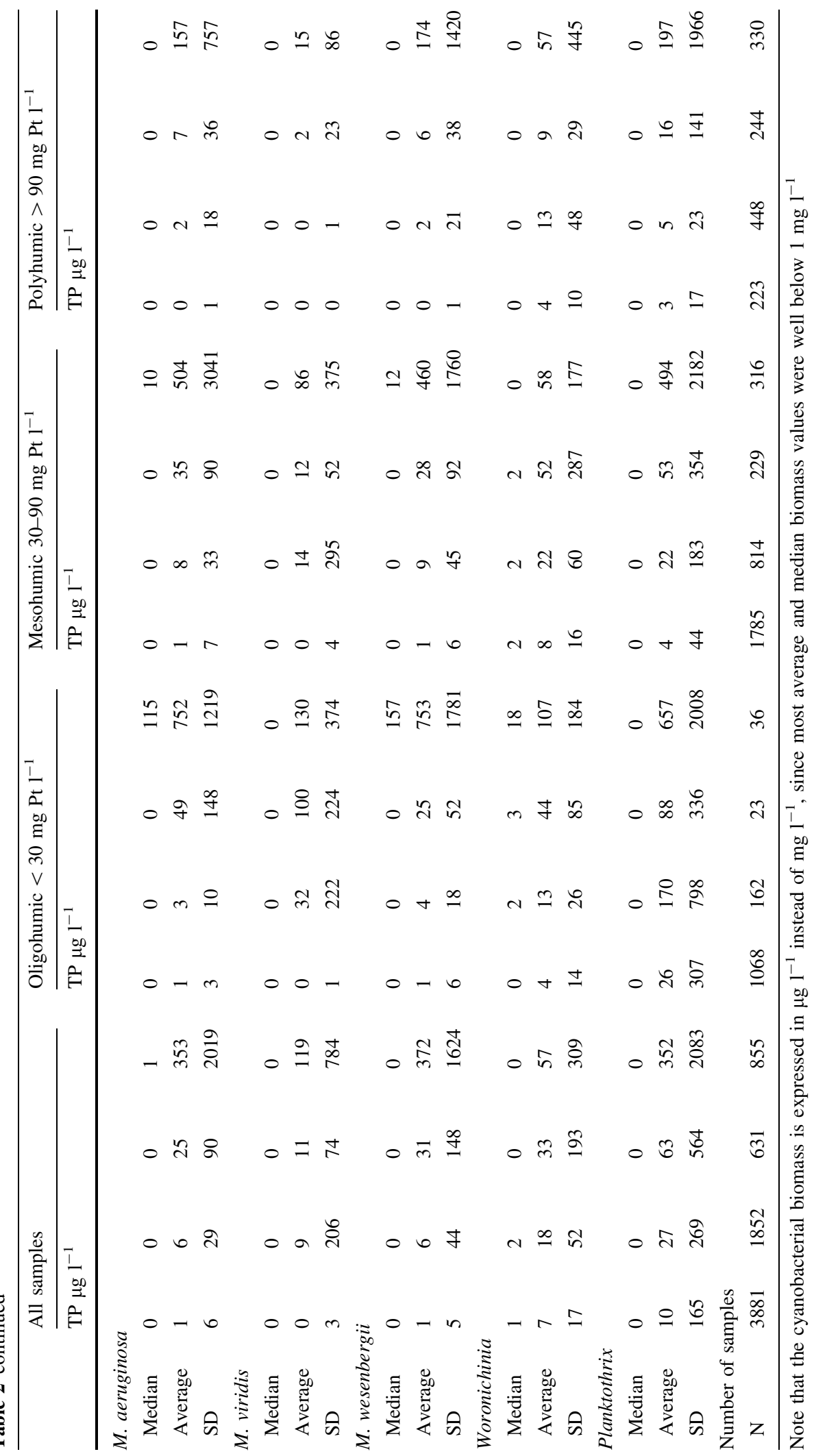


Table 3 An average threshold value (lower-upper 95\% confidence intervals) of total phosphorus (TP) for different cyanobacterial taxa

\begin{tabular}{|c|c|c|c|c|}
\hline \multirow[t]{2}{*}{ Taxon } & \multicolumn{4}{|l|}{ TP threshold } \\
\hline & All & Oligohumic & Mesohumic & Polyhumic \\
\hline Total cyanobacteria & $30(28-32)$ & $27(25-30)$ & $30(27-34)$ & $61(53-70)$ \\
\hline Aphanizomenon & $19(15-24)$ & $27(21-35)$ & $20(15-26)$ & $22 *$ \\
\hline Dolichospermum & $29(27-32)$ & $22(18-28)$ & $30(26-34)$ & $38(26-55)$ \\
\hline Dolichospermum straight filaments & $29(19-44)$ & & $27(17-44)$ & \\
\hline Dolichospermum flosaquae & $46(40-52)$ & & & \\
\hline Microcystis & $>20 *$ & $>20 *$ & $>20 *$ & $50(36-70)$ \\
\hline Woronichinia & $24(20-29)$ & & $38(2-56)$ & \\
\hline Planktohtrix & $15^{*}$ & $10(5-17)$ & $16^{*}$ & \\
\hline
\end{tabular}

The thresholds are estimated for the whole lake data-set and separately for lakes belonging to different water colour categories: oligohumic $<30 \mathrm{mg} \mathrm{Pt} 1^{-1}$, mesohumic $30-90 \mathrm{mg} \mathrm{Pt} 1^{-1}$ and polyhumic $>90 \mathrm{mg} \mathrm{Pt} 1^{-1}$. TP thresholds for the species $D$. lemmermannii, $M$. aeruginosa, $M$. viridis and $M$. wesenbergii could not be estimated due to consistently low biomass values

The asterisk (*) indicates values set by visual inspection of response curves. Total number of samples is 6939

biomass (e.g. Chorus \& Schanser, 2011; Carvalho et al., 2013). Based on our results, the increase of cyanobacterial biomass was more pronounced at TP concentrations $>30-50 \mu \mathrm{g}^{-1}$ (depending on the lake category), which corresponds to the WHO (2003) low-risk threshold. The WHO low-risk threshold approximately corresponds to TP concentration of 16-54 $\mathrm{g} \mathrm{I}^{-1}$ (Carvalho et al., 2013). Fairly similar TP thresholds for cyanobacterial biomass increase has been reported by Jeppesen et al. (1990) in shallow lakes and Dokulil \& Teubner (2000) in non-stratified lakes, as well as Chorus \& Schauser (2011) in German temperate lakes. Also, Fastner et al. (2016) have demonstrated that reduction of TP concentration below $20-50 \mu \mathrm{g} \mathrm{l}^{-1}$ can effectively control the formation of cyanobacterial biomass.

The genus-level TP threshold values varied between 15 and $46 \mu \mathrm{g}^{-1}$ (15-52 $\mu \mathrm{g} \mathrm{l}^{-1}$ including confidence intervals) across all humic categories. Chorus \& Schauser (2011) have reported similar TP threshold for Microcystis $\left(50 \mu \mathrm{g}^{-1}\right)$ from German temperate stratifying lakes, but higher TP threshold values (for Dolichospermum (Anabaena), Aphanizomenon and Planktothrix agardhii $\left(90 \mu \mathrm{g}^{-1}\right)$. Our analysis estimated clearly lower overall threshold values for these taxa (Aphanizomenon $19 \mu \mathrm{g} \mathrm{l}^{-1}$, Dolichospermum $29 \mu \mathrm{g} \mathrm{l}^{-1}$ and Planktothrix $15 \mu \mathrm{g} \mathrm{l}^{-1}$ ) in Finnish boreal lakes. The German lakes were more eutrophic and had the maximum TP concentration (600-800 $\left.\mu \mathrm{g} \mathrm{l}^{-1}\right)$ was $1.5-2$ times that of the Finnish lakes. Despite higher nutrient concentrations and alkalinity in temperate lakes (Maileht et al., 2013), the TP threshold for Microcystis was consistent between the climatic zones.

Statistical analysis in our study was limited to TP values less than $100 \mu \mathrm{g}^{-1}$. According to Dokulil \& Teubner (2000) Planktothrix agardhii and D. flosaquae dominate in lakes with TP $>100 \mu \mathrm{g}^{-1}$, and $P$. aghardhii generally disappears in shallow, non-stratifying lakes, with maximum depth less than $8 \mathrm{~m}$ at TP concentrations below $60 \mu \mathrm{g} \mathrm{l}^{-1}$. In our analysis, phytoplankton data represented the uppermost $2 \mathrm{~m}$ of the water column. This water layer has been shown to adequately represent the phytoplankton biomass of the photic/mixing water column in Finnish lakes (data not shown). Planktothrix species (e.g. P. rubescens) are known to form high biomass in the thermocline, where the nutrient concentrations are typically higher than in the epilimnion. In our dataset from Finnish lakes, the Planktothrix species was predominantly $P$. agardhii, which is known to favour turbulent conditions (Dokulil \& Teubner, 2000), and should therefore have been captured in our integrated 0-2 m samples. Planktothrix biomass was so low in our data that the segmented regression analysis was unable to determine the TP threshold for the taxon. Based on the visual inspection of the plots (see Fig. 3), the TP threshold for Planktothrix was less than $15 \mu \mathrm{g} \mathrm{l^{-1 }}$. 


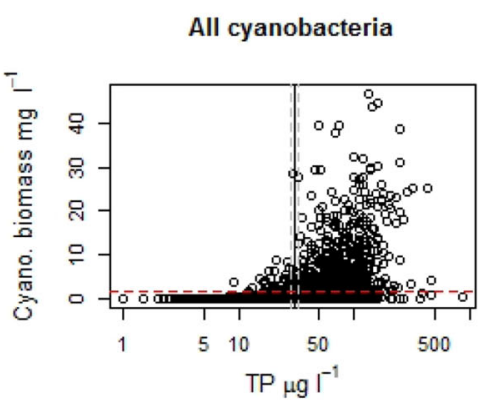

Dolichospermum straight filaments

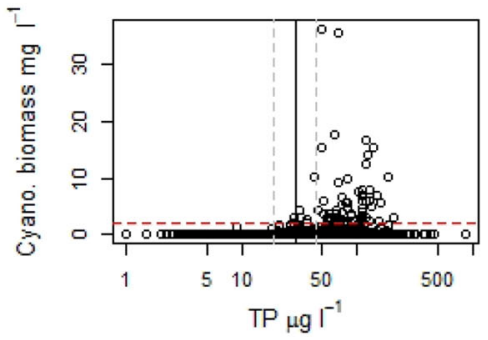

Microcystis

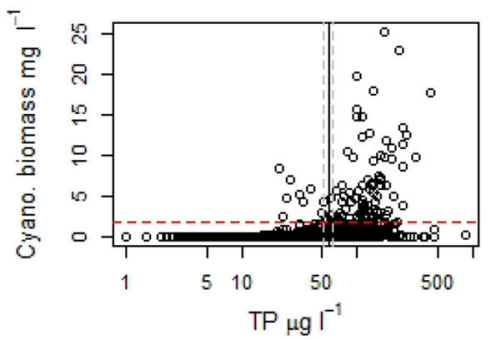

Microcystis viridis

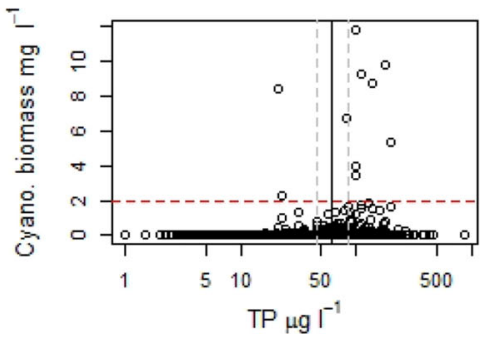

Aphanizomenon

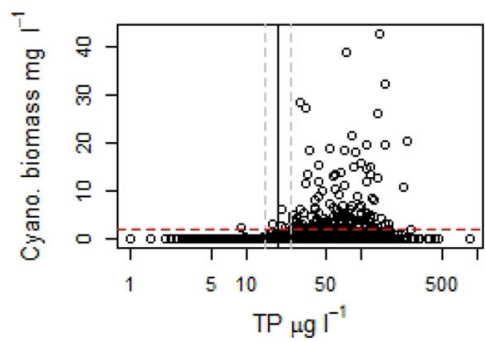

Dolichospermum flosaquae

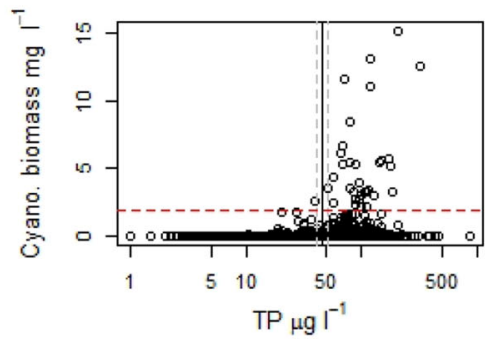

Microcystis aeruginosa

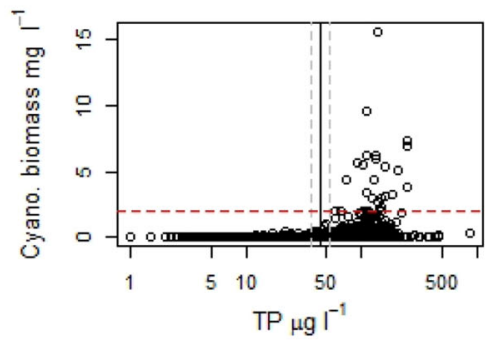

Woronichinia

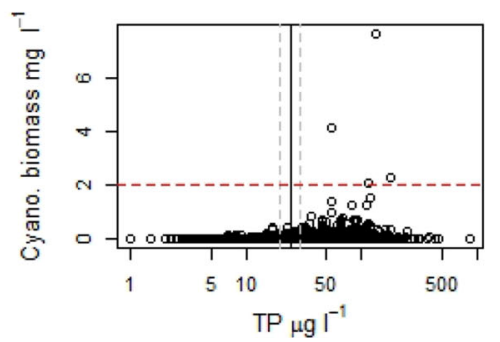

Dolichospermum

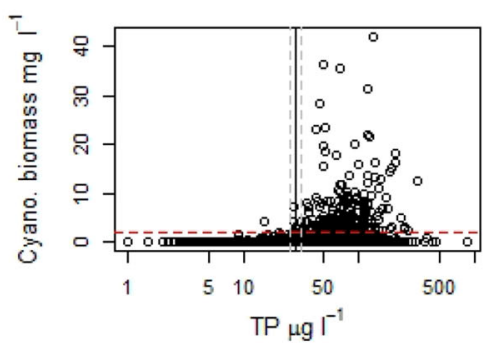

Dolichospermum lemmermannii

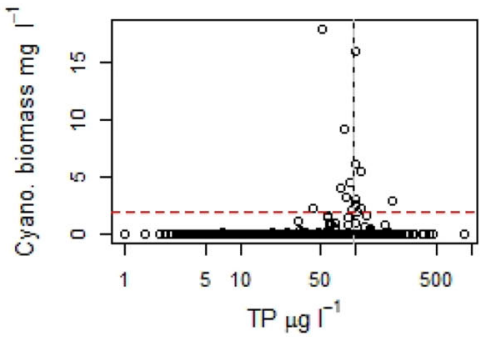

Microcystis wesenbergii

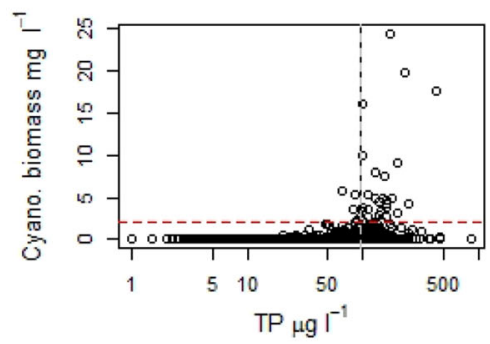

Planktohtrix

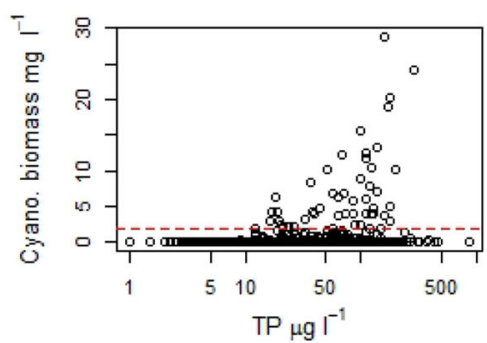

Fig. 3 Scatterplots of cyanobacterial biomass and $\log$ TP. The TP thresholds (solid line) and 95\% confidence interval (dashed lines) for the total cyanobacterial biomass, different

The value is, however, in agreement with Steinberg \& Hartmann (1988) who have reported that Planktohtrix can dominate in metalimnion at TP concentration of $10-15 \mu \mathrm{g} \mathrm{l}^{-1}$, which is the TP threshold for Planktothrix estimated in our study. cyanobacterial genera and species. The horizontal dotted line indicates WHO low health risk threshold of $2 \mathrm{mg} \mathrm{l}^{-1}$ (WHO, 2003). Note the differences in $Y$-axis scale

Climate change is expected to increase external and internal $\mathrm{P}$ loading and browning of waters, and to weaken the ecological status of waters (Jeppesen et al., 2009). Because boreal lakes are characterized by a high water colour gradient (due to dissolved organic carbon (DOC); Kortelainen, 1993; Eloranta \& 
Keskitalo, 1999), we were able to study the effect of water colour on the occurrence of cyanobacteria. Darker water colour means higher concentrations of humic substances that tend to bind phosphorus (e.g. Jones, 1992). Therefore, TP thresholds should be higher in mesohumic and polyhumic lakes than in oligohumic lakes. Our results supported this as we found higher TP threshold values for the increase of cyanobacterial biomass in polyhumic lakes. Although we determined TP thresholds for the increase of cyanobacterial biomass for many taxa, the thresholds for genera other than Aphanizomenon, Dolichospermum and Microcystis are rather uncertain, as the biomasses of many taxa were consistently low in the lake categories.

Cyanobacteria have superior phosphorus storage capacity (e.g. Istvánovics et al., 2002). It has been suggested, for example, that Microcystis species, which often occurring in shallow lakes, benefit from their ability for vertical migration, allowing them to fuel their $\mathrm{P}$ storage in water layers closer to the sediment (e.g. Cottingham et al., 2015). For that reason, migrating cyanobacteria may be less dependent on ambient TP concentration, which also makes it difficult to determine the correct TP thresholds.

The ecological threshold describes the point at which small changes in the stressor typically produce large responses in the ecosystem (Groffman et al., 2006). This approach is useful in setting evidencebased TP thresholds for the lake management purposes and in supporting the selection of appropriate measures (Kelly et al., 2015). However, and as our results demonstrate, efforts to set nutrient thresholds using automatic statistical algorithms, such as the segmented regression models used in this study, are not always straightforward. For example, from the lake manager's point of view, it is problematic that the abrupt-change method may detect too high threshold values (Gitzen et al., 2012). Therefore, as a precautionary measure, it would be better to set the TP target to the point where the gradual increase of cyanobacterial biomass begins and the cyanobacterial biomass does not exceed $2 \mathrm{mg} \mathrm{l}^{-1}$, which is the WHO low health risk threshold, corresponding TP of 16-54 $\mu \mathrm{g}^{-1}$. The target TP can be set utilising both the results of statistical analysis as well as supporting expert judgement. With this respect, our method identified the upper TP boundaries for stronger cyanobacterial biomass increase.

\section{Conclusion}

Considering nutrient thresholds as targets for the management of lakes would help achieve the management goals and may lead to improved efficiency and selection of appropriate restoration tools. The thresholds also provide a means to improve communication and understanding among river basin managers, researchers and stakeholders, and to increase the possibility to monitor the success of the management measures applied. Our study shows that in boreal lakes, the most dramatic decrease in cyanobacterial biomass would occur at TP concentrations below $50 \mu \mathrm{g} \mathrm{l}^{-1}$. This is often not enough for management purposes, as the target concentration to avoid harmful cyanobacterial biomasses seems to be much stricter, ca Phosphorus thresholds for bloom-forming cyanobacterial taxa in boreal lakes $20-30 \mu \mathrm{g} \mathrm{TP} 1^{-1}$ in clearwater (oligohumic) and mesohumic lakes (Table 3). However, in polyhumic lakes, reduction of $\mathrm{TP}$ concentration to less than $50 \mu \mathrm{g} \mathrm{l^{-1 }}$ may be sufficient to avoid high levels of cyanobacterial biomasses, because of lower alkalinity (lower $\mathrm{HCO}_{3}$ concentration), shallower photic zone (due to higher water colour) and the high abundance of humic substances (able to bind $\mathrm{P}$ ). Our results emphasize that when setting TP reduction targets to avoid high abundance of cyanobacterial biomass, both water colour of the lake water as well as the composition of cyanobacteria species present in the lake, must be taken into account.

Acknowledgements Open access funding provided by Finnish Environment Institute (SYKE). We thank Sari Mitikka for her invaluable help in data collection. The study was funded by the Academy of Finland (Projects 263472 TERLA and 311229 MiDAS) awarded for K.V and M.J. and the Strategic Research Council of Academy of Finland (Project 312650 BlueAdapt) awarded to N.K.

Open Access This article is licensed under a Creative Commons Attribution 4.0 International License, which permits use, sharing, adaptation, distribution and reproduction in any medium or format, as long as you give appropriate credit to the 
original author(s) and the source, provide a link to the Creative Commons licence, and indicate if changes were made. The images or other third party material in this article are included in the article's Creative Commons licence, unless indicated otherwise in a credit line to the material. If material is not included in the article's Creative Commons licence and your intended use is not permitted by statutory regulation or exceeds the permitted use, you will need to obtain permission directly from the copyright holder. To view a copy of this licence, visit http://creativecommons.org/licenses/by/4.0/

\section{References}

Bormans, M., B. Maršálek \& D. Jančula, 2016. Controlling internal phosphorus loading in lakes by physical methods to reduce cyanobacterial blooms: a review. Aquatic Ecology 50: 407-422.

Carvalho, L., C. A. Miller, E. M. Scott, G. A. Codd, P. S. Davies \& A. Tyler, 2011. Cyanobacterial blooms: statistical models describing risk factors for national-scale lake assessment and lake management. Science of the Total Environment 409: 5353-5358.

Carvalho, L., S. Poikane, A. Lyche Solheim, G. Phillips, G. Borics, J. Catalan, C. De Hoyos, S. Drakare, B. J. Dudley, M. Järvinen, C. Laplace-Treyture, K. Maileht, C. McDonald, U. Mischke, J. Moe, G. Morabito, P. Nõges, T. Nõges, I. Ott, A. Pasztaleniec, B. Skjelbred \& S. J. Thackeray, 2012. Strength and uncertainty of lake phytoplankton metrics for assessing eutrophication impacts in lakes. Hydrobiologia 704: 127-140.

Carvalho, L., C. McDonald, C. de Hoyos, U. Mischke, G. Phillips, G. Borics, S. Poikane, B. Skjelbred, A. Lyche Solheim, J. Van Wichelen \& A. C. Cardoso, 2013. Sustaining recreational quality of European lakes: minimizing the health risks from algal blooms through phosphorus control. Journal of Applied Ecology 50: 315-323.

CEN EN 15204, 2006. Water quality-Guidance standard for the routine analysis of phytoplankton abundance and composition using inverted microscopy (Utermöhl technique).

Chorus I. \& I. Schauser, 2011. Oligotrophication of lake Tegel and Schlachtensee, Berlin-analysis of system components, causalities and response thresholds compared to responses of other waterbodies. Technical report (45/2011) of the Federal Environment Agency (Umweltbundesamt).

Codd, G. A., S. G. Bell, K. Kaya, C. J. Ward, K. A. Beattie \& J. S. Metcalf, 1999. Cyanobacterial toxins, exposure routes and human health. European Journal of Phycology 34: $405-415$.

Codd, G. A., J. Lindsay, F. M. Young, L. F. Morrison \& J. S. Metcalf, 2005. Harmfull Cyanobacteria. From mass mortalities to management measures. In Huisman, J., H. C. P. Matthijs \& P. M. Visser (eds), Harmful Cyanobacteria. Springer, The Netherlands: 1-24.

Cottingham, K. L., H. A. Ewing, M. L. Greer, C. C. Carey \& K. C. Weathers, 2015. Cyanobacteria as biological drivers of lake nitrogen and phosphorus cycling. Ecosphere 6(1): 1.
Dokulil, M. T. \& K. Teubner, 2000. Cyanobacterial dominance in lakes. Hydrobiologia 438: 1-12.

Downing, J. A., S. G. Watson \& E. McCauley, 2001. Predicting cyanobacteria dominance in lakes. Canadian Journal of Fisheries and Aquatic Sciences 58: 1905-1908.

Elliott, J. A., 2012. Is the future blue-green? A review of the current model predictions of how climate change could affect pelagic freshwater cyanobacteria. Water Research 46: 1364-1371.

Eloranta, P. \& J. Keskitalo, 1999. Limnology of Humic Waters. Backhyus Publishers, Leiden.

Fastner, J., S. Albella, A. Litt, G. Morabito, L. Vörös, K. Pálff, D. Straile, R. Kümmerlin, D. Matthews, M. G. Phillips \& I. Chorus, 2016. Combating cyanobacterial proliferation by avoiding or treating inflows with high $\mathrm{P}$ load - experiences from eight case studies. Aquatic Ecology 50: 367-383.

Gallant, A. R. \& W. A. Fuller, 1973. Fitting segmented polynomial regression models whose join points have to be estimated. Journal of the American Statistical Association 68: 144-147.

Gitzen, R. A., J. J. Millspaugh, A. B. Cooper \& D. S. Licht (eds), 2012. Design and analysis of long-term ecological monitoring studies. Cambridge University Press, Cambridge.

Groffman, P. M., J. S. Baron, T. Blett, A. J. Gold, I. Goodman, L. H. Gunderson, B. M. Levinson, M. A. Palmer, H. W. Paerl, G. D. Peterson, N. LeRoy Poff, D. W. Rejeski, J. F. Reynolds, M. G. Turner, K. C. Weathers \& J. Wiens, 2006. Ecological thresholds: the key to successful environmental management or an important concept with no practical application? Ecosystems 9: 1-13.

Huber, V., C. Wagner, A. Gerten \& R. Adrian, 2012. To bloom or not to bloom: contrasting responses of cyanobacteria to recent heat waves explained by critical thresholds of abiotic drivers. Oecologia 169: 245-256.

Istvánovics, V., L. Somlyódy \& A. Clement, 2002. Water Research Cyanobacteria-mediated internal eutrophication in shallow Lake Balaton after load reduction. Water Research 36: 3314-3322.

Jeppesen, E., J. P. Jensen, P. Kristensen, M. Søndergaard, E. Mortensen, O. Sortkjær \& K. Olrik, 1990. Fish manipulation as a lake restoration tool in shallow, eutrophic temperate lakes 2: threshold levels, long-term stability and conclusion. Hydrobiologia 200(201): 219-227.

Jeppesen, E., B. Kronvang, M. Meerhoff, M. Søndergaard, K. M. Hansen, H. E. Andersen, T. L. Lauridsen, L. Liborussen, M. Beklioglu, A. Özen \& J. E. Olesen, 2009. Climate change effects on runoff, cathment phosphorus loading and lake ecological state, and potential adaptations. Journal of Environmental Quality 38: 1930-1941.

Jones, R., 1992. The influence of humic substances on lacustrine planktonic food chains. Hydrobiologia 229: 73-91.

Jones, R. A. \& G. F. Lee, 1986. Recent advances in assessing impact of phosphorus loads on eutrophication-related water quality. Water Research 16: 503-515.

Kelly, R. P., A. L. Erikson, L. A. Mease, W. Battista, J. N. Kittinger \& R. Fujita, 2015. Embracing thresholds for better environmental management. Philosophical Transactions of the Royal Society B 370: 20130276.

Kortelainen, P., 1993. Content of total organic carbon in Finnish lakes and its relationship to chatchment characteristics. 
Canadian Journal of Fisheries and Aquatic Sciences 50: 1477-1483.

Maileht, K., T. Nôges, P. Nôges, I. Ott, U. Mischke, L. Carvalho \& B. Dudley, 2013. Water colour, phosphorus and alkalinity are the major determinants of the dominant phytoplankton species in European lakes. Hydrobiologia 704: $115-126$.

Mitikka, S. \& P. Ekholm, 2003. Lakes in the Finnish Eurowaternet: status and trends. The Science of the Total Evironment 310: 37-45.

Muggeo, V. M. R., 2003. Estimating regression models with unknown break-points. Statistics in Medicine 22: 3055-3071.

Muggeo, V. M. R., 2008. Segmented: an R Package to Fit Regression Models with Broken-Line Relationships. R News, 8/1, 20-25. https://cran.r-project.org/doc/Rnews_ 2008-1.pdf.

Paerl, H. W. \& J. Huisman, 2008. Blooms like it hot. Science 320: $57-58$.

Paerl, H. \& J. Huisman, 2009. Climate change: a catalyst for global expansion of harmful cyanobacterial blooms. Enrironmental Microbiology Reports 1: 27-37.

Paerl, H. W. \& V. J. Paul, 2012. Climate change: links to global expansion of harmful cyanobacteria. Water Research 46: 1349-1363.

Paerl, H. W., R. S. Fulton, P. H. Moisander \& J. Dyble, 2001. Harmful freshwater algal blooms, with an amphasis on cyanobacteria. The Scientific World 1: 76-113.

Peltomaa, E. T., S. L. Aalto, K. M. Vuorio \& S. J. Taipale, 2017. The importance of phytoplankton biomolecule availability for secondary production. Frontiers in Ecology and Evolution 5: 128.

R Core Team, 2018. R: A language and environment for statistical computing. R Foundation for Statistical Computing, Vienna, Austria. https://www.R-project.org/.

Reynolds, C. S., 2006. Ecology of Phytoplankton. Cambridge University Press, Cambridge.

Shapiro, J., 1990. Current beliefs regarding dominance of bluegreens: the case for the importance of $\mathrm{CO}_{2}$ and $\mathrm{pH}$. Internationale Vereinigung für Theoretische und Angewandte Limnologie 24: 38-54.

Søndergaard, M., L. Liboriussen, A. R. Pedersen \& E. Jeppesen, 2008. Lake restoration by fish removal: short- and long- term effects in 36 Danish lakes. Ecosystems 11: 1291-1305.

Steinberg, C. E. W. \& H. M. Hartmann, 1988. Planktonic bloomforming cyanobacteria and the eutrophication of lakes and rivers. Freshwatater Biology 20: 279-287.

Taipale, S., U. Strandberg, E. Peltomaa, A. W. Galloway, A. E. Ojala \& M. T. Brett, 2013. Fatty acid composition as biomarkers of freshwater microalgae: analysis of 37 strains of microalgae in 22 genera and seven classes. Aquatic Microbial Ecology 71: 165-178.

Triest, L., I. Stiers \& S. Van Omsen, 2016. Biomanipulation as a nature-based solution to reduce cyanobacterial blooms. Aquatic Ecology 50: 461-483.

Vollenweider, R. A., 1968. Scientific fundamentals of the eutrophication of lakes and flowing waters, with particular reference to nitrogen and phosphorus as factors in eutrophication. Organization for Economic Cooperation and Development, Paris, Technical Report. DAS/CSI/ $68.27,250$

Wagner, C. \& R. Adrian, 2009. Cyanobacteria dominance: quantifying the effects of climate change. Limnology and Oceanography 54: 2460-2468.

Weyhenmeyer, G. A., R. Adrian, U. Gaedke, D. M. Livingstone \& S. C. Maberly, 2002. Response of phytoplankton in European lakes to a change in the North Atlantic Oscillation. Verhandlungen der Internationale Vereinigung für Limnologie 28: 1436-1439.

WHO, 2003. Guidelines for Safe Recreational Water Environments: Coastal and Fresh Waters. Volume 1. Coastal and fresh waters.

WHO, 2004. Guidelines for Drinking-water Quality, 3rd ed. World Health Organisation, Geneva.

Xu, H., H. W. Paerl, B. Qin, G. Zhu, N. S. Hall \& Y. Wu, 2014. Determining critical nutrient thresholds needed to control harmful cyanobacterial blooms in eutrophic Lake Taihu, China. Environmental Science \& Technology 49: 1051-1059.

Publisher's Note Springer Nature remains neutral with regard to jurisdictional claims in published maps and institutional affiliations. 